ERDC TN-EWN-17-1

March 2017

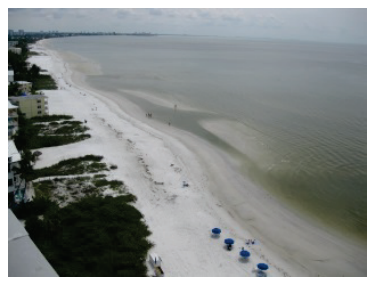

\title{
Strategic Placement of Mixed Sediment in the Form of a Nearshore Berm along Fort Myers Beach, Florida
}

\author{
By Katherine E. Brutsché and Cheryl E. Pollock
}

PURPOSE: The Engineering With Nature (EWN) program explores the partnering of engineering with naturally occurring physical processes to achieve a desired benefit. This technical note (TN) documents the application of EWN practices as applied to the strategic placement of a nearshore berm at Fort Myers Beach, FL, to accommodate sediments that exceed regulatory limits for the percentage of fine material that can be used for beach placement yet still allowing the dredged materials to be used to benefit the nearshore region. EWN practices exhibited by this study include the following:

1. The winnowing of sediments by waves and currents reduces the percent fine content of the placed sediment and modifies the nearshore material such that it may comply with regulatory requirements for beach compatibility.

2. The onshore migration of the sediment nourishes the nearshore profile through wave and current processes.

3. Sediments that remain at a nearshore placement site are naturally sorted and winnowed to potentially build a storage supply of acceptable material that may be mined and placed on the beach at a future time.

4. Fine grain sediment that is sorted from the placed material will not move onto the beach due to the higher energy, thus yielding beach quality material.

5. Some designs of nearshore placements can result in the placed material slowly migrating from the placement area, yielding a reusable and sustainable placement site.

6. The nearshore berm will allow increased shore protection from large waves breaking and attenuating on the berm rather than at the shoreline.

Detailed in this EWN TN are the sediment characteristics and morphological evolution of the strategic placement of a nearshore berm consisting of mixed sediment placed just offshore of Fort Myers Beach, FL, based on a series of field data collection efforts from construction through the equilibration of the berm with the natural system. Pre-placement vibracores taken by the U.S. Army Corps of Engineers (USACE), Jacksonville District (SAJ), indicated that the composite silt material was not within the allowable limits for beach placement of dredged material in the state of Florida, but by placing the material in a nearshore berm in the active nearshore profile, SAJ's expectation was that the fine material in the berm would move offshore 
while coarser, beach quality sediment would move onshore ${ }^{1}$. Additionally, it was expected that the berm sediment would migrate onshore and nourish the beach while sustaining the usability of the strategic placement site. Supplemental technical details can be found in Brutsché (2011), Brutsché and Wang (2012), Wang et al. (2013), and Brutsché et al. (2014). The Fort Myers Beach nearshore berm project provided an excellent example of utilizing EWN practices for strategic design and placement along with EWN practices to gain benefit from sediments that otherwise would have been relegated to placement in offshore or upland sites.

BACKGROUND: Matanzas Pass is a Federally maintained navigation channel north of Estero Island on the west coast of Florida (Figure 1). It serves as a passageway for fishing boats and recreational boats as well as the primary access for the U.S. Coast Guard. The pass was dredged for maintenance in 1986, 1996, and 2001 (Florida Department of Environmental Protection 2009). In the past, as part of regional sediment management, sediment dredged from the channel was placed on the beach and in the nearshore. By 2009, the channel had shoaled since the 2001 dredging, creating hazardous boating conditions as many boaters grounded after having to navigate around the tip of the island into the shallow waters of San Carlos Bay. Maintenance dredging of the channel as well as Bowditch Point (the northern most point on the island, Figure 1) occurred in July 2009 (Florida Department of Environmental Protection 2009).
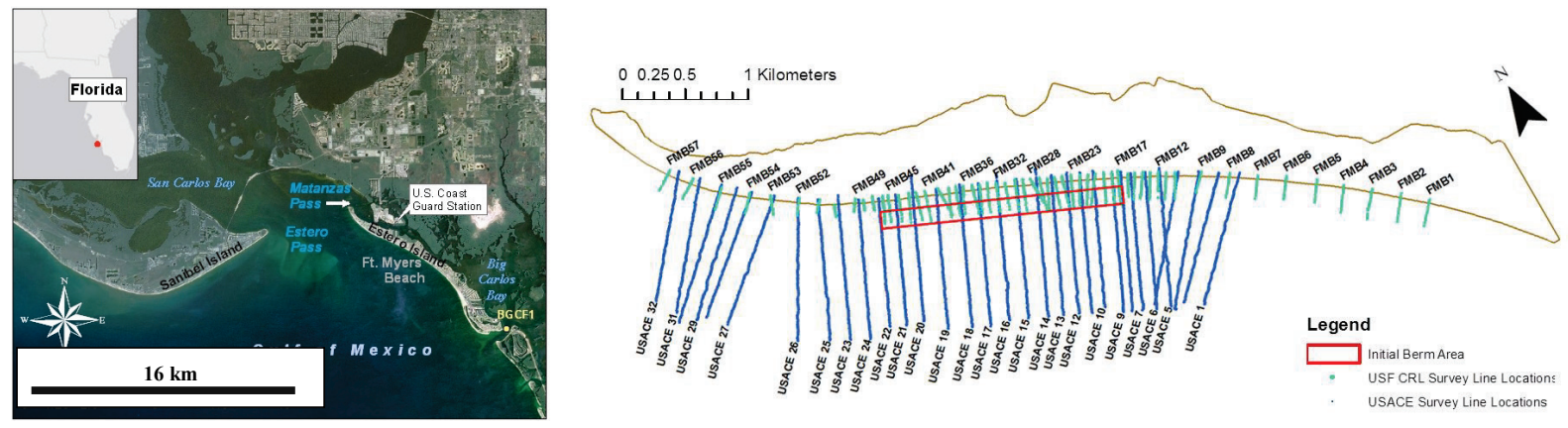

Figure 1. Study area and survey line locations. Sanibel Island (to the northwest of Estero Island) shelters Fort Myers Beach from large waves coming from the northwest.

Based on seven vibracores and one grab sample within the proposed dredge cut, it was found that the composite silt content of the material was $7.71 \%$. However, five of the vibracores contained silt content greater than $10 \%$, which is above the allowable limit for beach placement of maintenance dredged material in the state of Florida (Rule 62B-41.007(2)(j\&k)) (Florida Department of Environmental Protection 2009; Florida Department of State 2001). Additionally, several layers throughout the cores contained silt contents higher than the acceptable limit for beach placement. It was not believed that the dredged material from the cut would mix to create a uniform silt content of $7.71 \%$ that would be acceptable for beach placement; therefore, a nearshore berm was chosen as the alternative. By placing the material in the nearshore, coastal processes would be relied upon to sort, transport, and deposit coarse material landward of the berm while fine material would move offshore. Overall, the mean grain size of the dredge material was 2.64 phi $(0.16$ millimeters [mm]) with a 0.65 phi sorting value (Florida Department of Environmental Protection 2009).

${ }^{1}$ James Lagrone, SAJ, personal communication, 2011. 
Once dredged, the material was placed in the nearshore along Fort Myers Beach. The nearshore berm was not uniform alongshore and was constructed to be much larger than the small natural bar that exists in the area. Generally, the nearshore berm was approximately 1.6 kilometers $(\mathrm{km})$ long, 120 meters $(\mathrm{m})$ wide at its base, and $1 \mathrm{~m}$ high, with a total volume of 175,000 cubic meters $\left(\mathrm{m}^{3}\right)$. Waves in this area are generally small, except during high wave energy events such as winter cold fronts (occurring approximately every 10 to 14 days, October through April; Beck and Wang [2012]) or tropical systems. According to the Wave Information Study (WIS) (http://wis.usace. army.mil/) hindcast station 73296, average offshore wave height in the study area is approximately $0.46 \mathrm{~m}$, with average peak wave period of 4.4 seconds (s). However, due to the sheltering effects of nearby Sanibel Island (Balsillie and Clark 1992), the wave heights closer to the study area are much lower. This is reflected in WIS hindcast station 73295, only $5 \mathrm{~km}$ offshore in $5 \mathrm{~m}$ of water. The average wave height from the nearshore hindcast station is $0.22 \mathrm{~m}$ with average wave period of $3.7 \mathrm{~s}$. The study area is influenced by a mixed tide regime, with spring tides being diurnal and neap tides being semidiurnal. Tidal ranges are $1.2 \mathrm{~m}$ and $0.75 \mathrm{~m}$ for spring and neap tides, respectively (according to NOAA gauge 8725110).

Direction of net longshore sediment transport varies along the study area. The shoaling of Matanzas Pass would indicate a northward longshore sediment transport, which was verified by a USACE (1969) report that determined that the north end of the island (defined as $3 \mathrm{~km}$ south of Matanzas Pass) experiences longshore sediment transport to the north at a rate estimated to be $17,000 \mathrm{~m}^{3} /$ year. The same report determined that the south end of the island experiences southward longshore sediment transport at an approximate rate of $50,000 \mathrm{~m}^{3} /$ year (USACE 1969). Another USACE (2001) report stated that the longshore transport rate varies along Estero Island from 0 to $53,000 \mathrm{~m}^{3} /$ year, citing Walton (1973) as evidence for the maximum value. Poff and Stephen (1998) estimated that the maximum longshore transport rate for the island is $22,000 \mathrm{~m}^{3} /$ year. The protrusion of Sanibel Island blocking waves from the north and northwest creates the longshore sediment transport reversal along the northern portion of the island (Balsillie and Clark 1992; USACE 1969; USACE 2001). The center of the nearshore berm was placed at the estimated point of reversal of longshore sediment transport.

As a strategic placement project, Fort Myers Beach offers an excellent example of EWN practices including maximizing benefits to the environment by adding sediment to the littoral system while minimizing negative impacts. Additionally, this strategic placement contained mixed sediment with a relatively high fines content, and therefore data collected during this study provides information on transport and deposition of both the fine sediment and the beach quality sand.

FIELD DATA COLLECTION EFFORT: The field study was based on sediment and morphology data collected over a 4-year study period (Brutsché et al. 2014). Pre- and postplacement surveys were conducted by the SAJ in May 2009 and October 2009, respectively. Beginning April 2010 until May 2013, beach profile transects were established, and surveys were conducted bimonthly to semiannually by the Coastal Research Lab at the University of South Florida (USF) for a total of eight survey periods (Figure 1). The study area includes the nearshore berm project area and control areas $1.6 \mathrm{~km}$ northwest and southeast of the berm, respectively. Beach profile transects in the control areas were set at approximately $200 \mathrm{~m}$ intervals while lines over the nearshore berm were set at approximately $50 \mathrm{~m}$ intervals. For the purposes of this EWN $\mathrm{TN}$, the control areas will not be discussed in detail. The beach-nearshore profiles were surveyed using an electronic total station following standard level-transect procedures, extending to 
approximately $2.5 \mathrm{~m}$ water depth. Sediment sampling took place along 11 transects in the project and control areas in April 2010 and June 2011. In the berm project area, 10-11 samples were taken across five transects while in the control areas, 7-9 samples were taken across six transects for a total of over 200 samples. Vibracores were also extracted in November 2010. Five cores were taken along three transects in the berm project area while two cores were taken along transects in the control areas. Samples were taken from the cores in each described layer, or at $0.5 \mathrm{~m}$ spacing, whichever was a shorter distance. Using a 4 phi $(0.063 \mathrm{~mm})$ sieve, wet sieving was performed to separate the fine fraction of sediment. Standard dry sieving was performed on the remaining coarser fraction.

\section{PROJECT RESULTS}

Morphology change of the nearshore berm. Survey line FMB 32 (Figures 2 and 3) is a typical example showing the morphologic evolution of the berm project area through time series beach profile surveys beginning with the pre-placement survey through the final survey in May 2013 (survey lines indicated by dates: month and year). The natural (pre-placement) profile morphology includes a small bar approximately $0.5 \mathrm{~m}$ high, $100 \mathrm{~m}$ offshore. As indicated by the control area profiles (Figure 4 and detailed in Brutsché [2011]; Brutsché and Wang [2012]; Wang et al. [2013]; Brutsché et al. [2014]), the small natural bar is dynamic and ephemeral. Generally, onshore migration of the berm occurred throughout the entire 4-year study period. Immediately following the placement through April 2010 (approximately 6 months) the nearshore berm crest migrated onshore $50 \mathrm{~m}$. During the relatively calm summer months, the berm migrated onshore less than $10 \mathrm{~m}$. The berm continued to migrate, totaling an overall onshore migration during the first 2 years approximately $100 \mathrm{~m}$ (Figure 2). The shape of the berm changed from a symmetric bell shape to an asymmetric shape with a steep landward slope, which is also an indication of onshore movement (Larson and Kraus 1994; Roberts and Wang 2012). Volume change during that time appeared to be negligible. Note that the beach remained stable during the first 2 years post-placement (Figure 2).

During the third year post-placement, the study area was impacted by Tropical Storm Debby and Hurricane Isaac in June 2012 and August 2012, respectively. Tropical Storm Debby (Figure 3; 0712 survey) split the large berm into two bars, yet remained generally in the same place. No significant erosion occurred on the dry beach. Hurricane Isaac (Figure 3; 0912 survey) caused the two smaller bars to become less well defined, and created a small amount of erosion in the intertidal zone. By May 2013, the shape of the profile resembled the pre-placement profile, however, shifted offshore, indicating an overall volume gain across the profile. The dry beach gained approximately $18 \mathrm{~m}$ in width over the 4-year study period. 


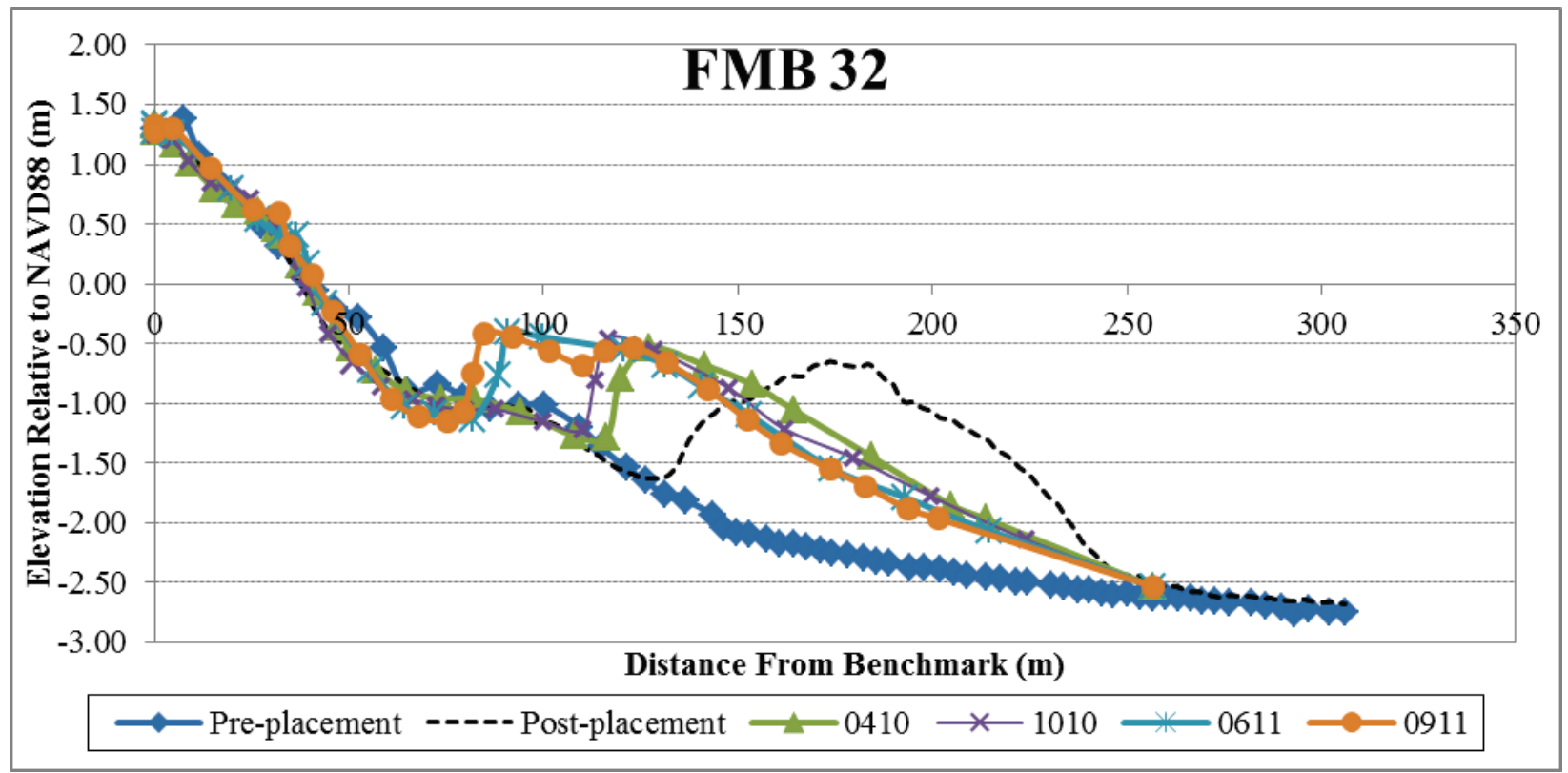

Figure 2. Example profile within the berm project area during the first 2 years post-placement. Modified from Brutsché et al. (2014).

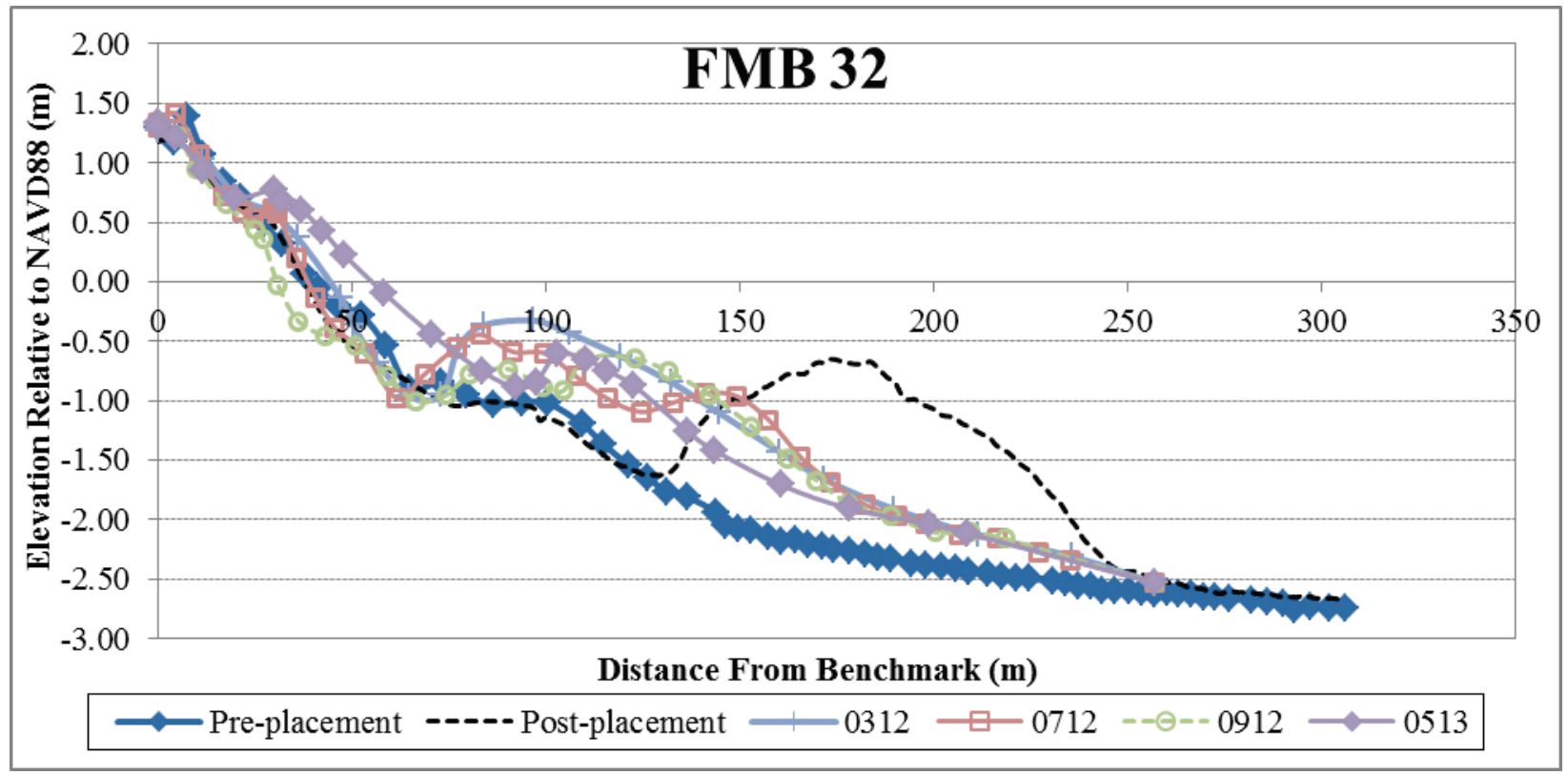

Figure 3. Example profile within the berm project area during the first 2 years post-placement. Modified from Brutsché et al. (2014). 


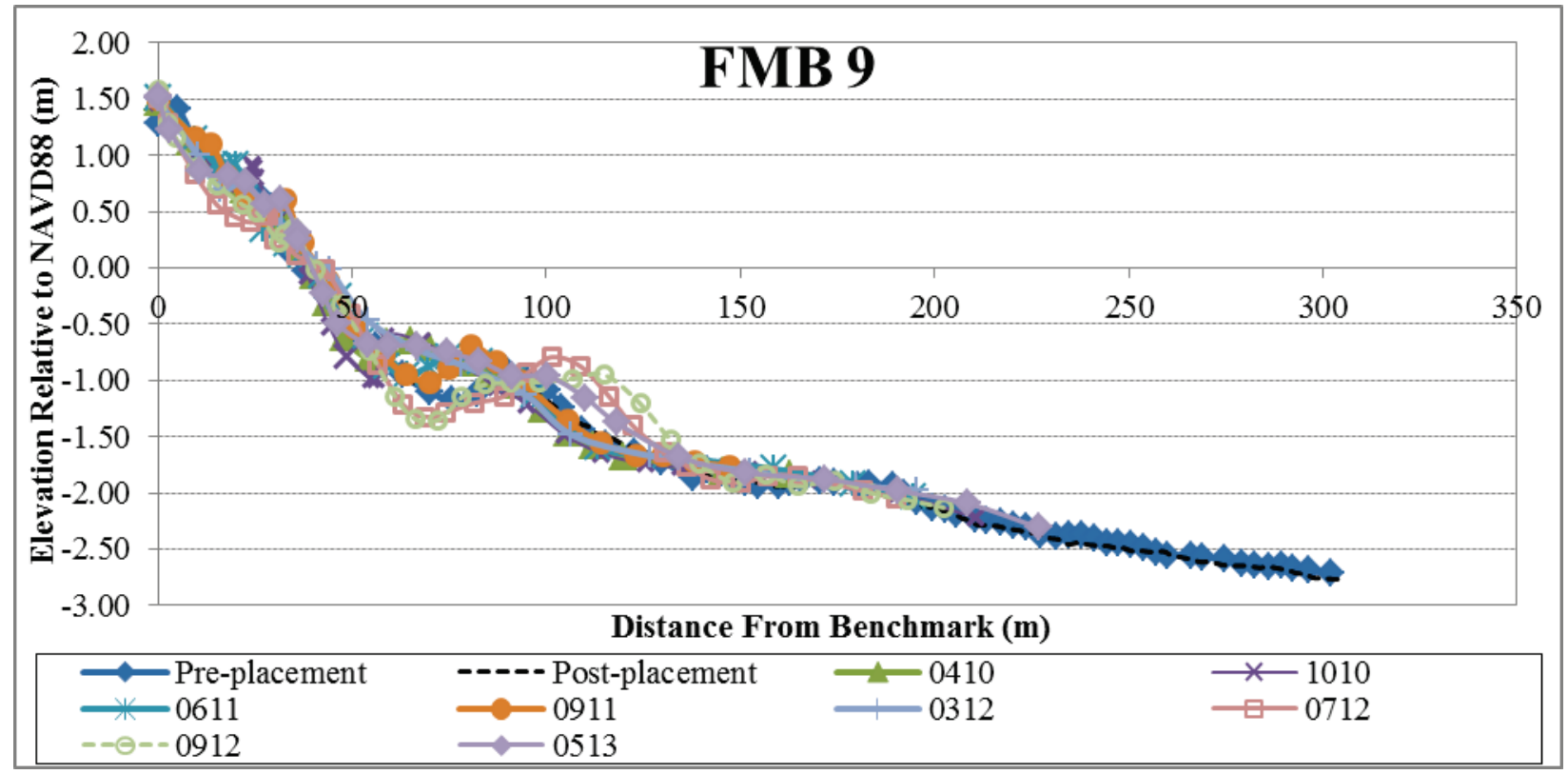

Figure 4. Example profile within the southeast control area during the first 2 years post-placement.

Sediment characteristics. The dredged material from Matanzas Pass contained up to $16.15 \%$ silt content. Two surface sediment sampling periods were conducted in April 2010 and June 2011. Cores were extracted in November 2010.

Initially, the finest sediment was found in the offshore of the southeast control area, indicating that fine sediment is native to the study area. In the berm project area, the finest sediment was found in the trough landward of the berm, with percentages up to approximately $42 \%$ (Figure 5). Percentage of fine material is relatively low on the beach and nearshore, with percentages up to approximately 2\%. By June 2011, the percentage of fines located in the trough decreased to just over $1 \%$ while the offshore percentages increased up to almost $11 \%$ (Figure 6). Although, the previous example is one transect, the trend of decreasing fines in the trough and on the berm and increase in fines seaward of the berm is consistent throughout the berm project area. Figure 7 shows spatially averaged grain sizes within the berm project area. The overall increase in grain size in the trough and decreasing grain size in the offshore between 2010 and 2011 is apparent. The coarser surface samples in 2010 over the berm crest as compared to the fine subsurface samples in the cores later in 2010 suggest a winnowing of fine sediment. 


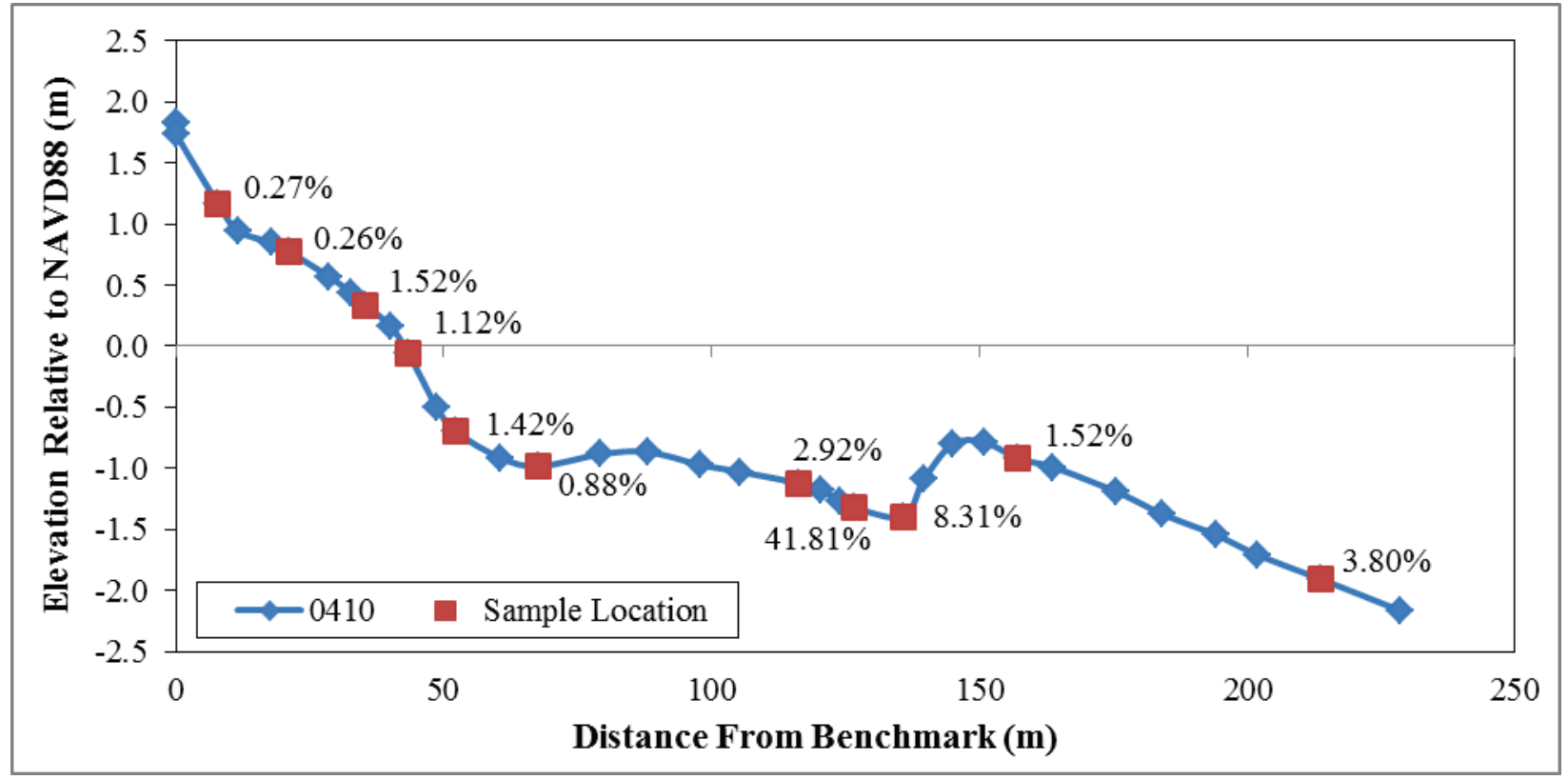

Figure 5. Percent fines indicated along an example profile for April 2010. From Brutsché et al. (2014).

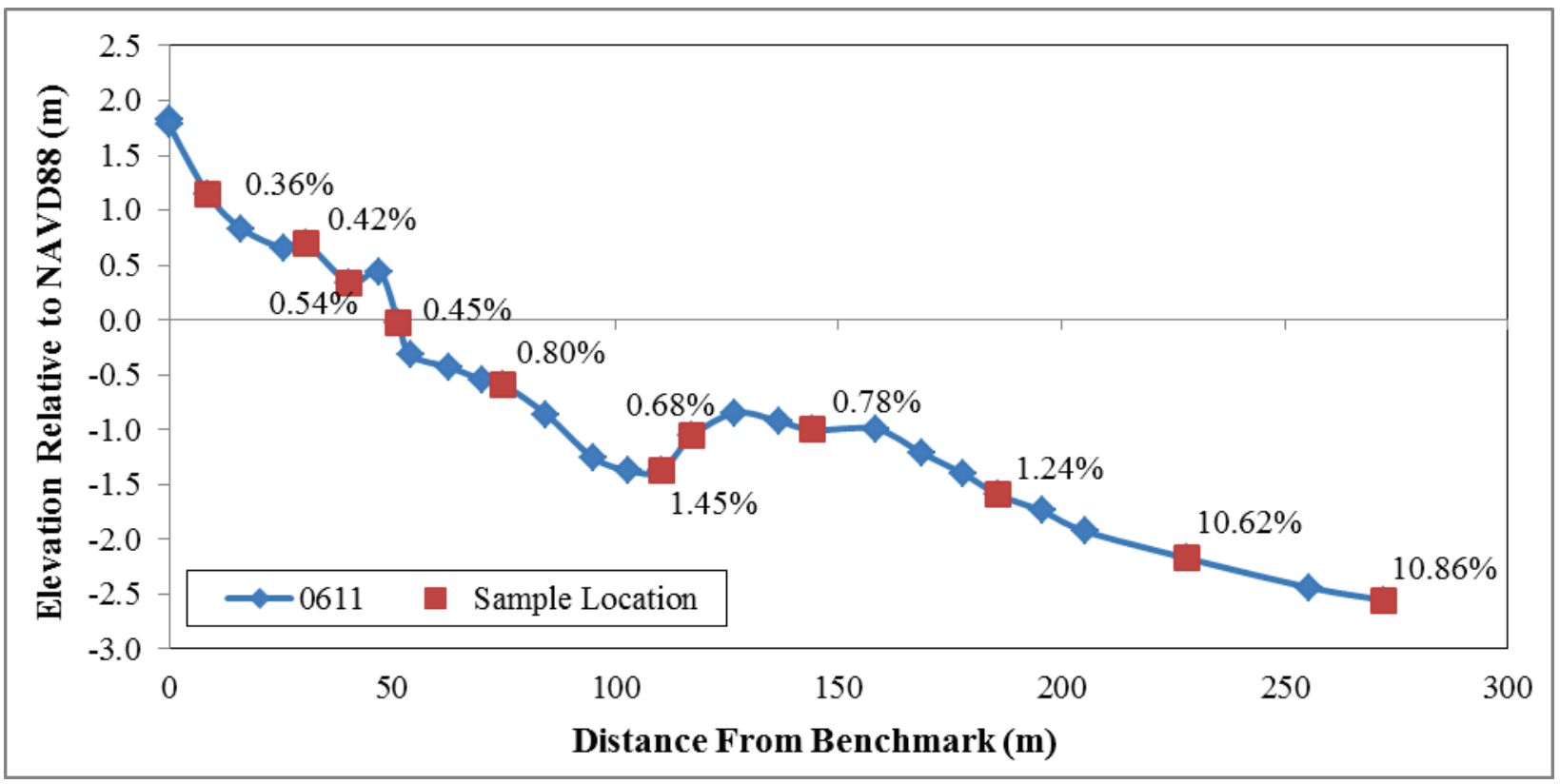

Figure 6. Percent fines indicated along an example profile for June 2011. From Brutsché et al. (2014).

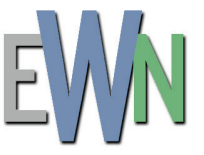




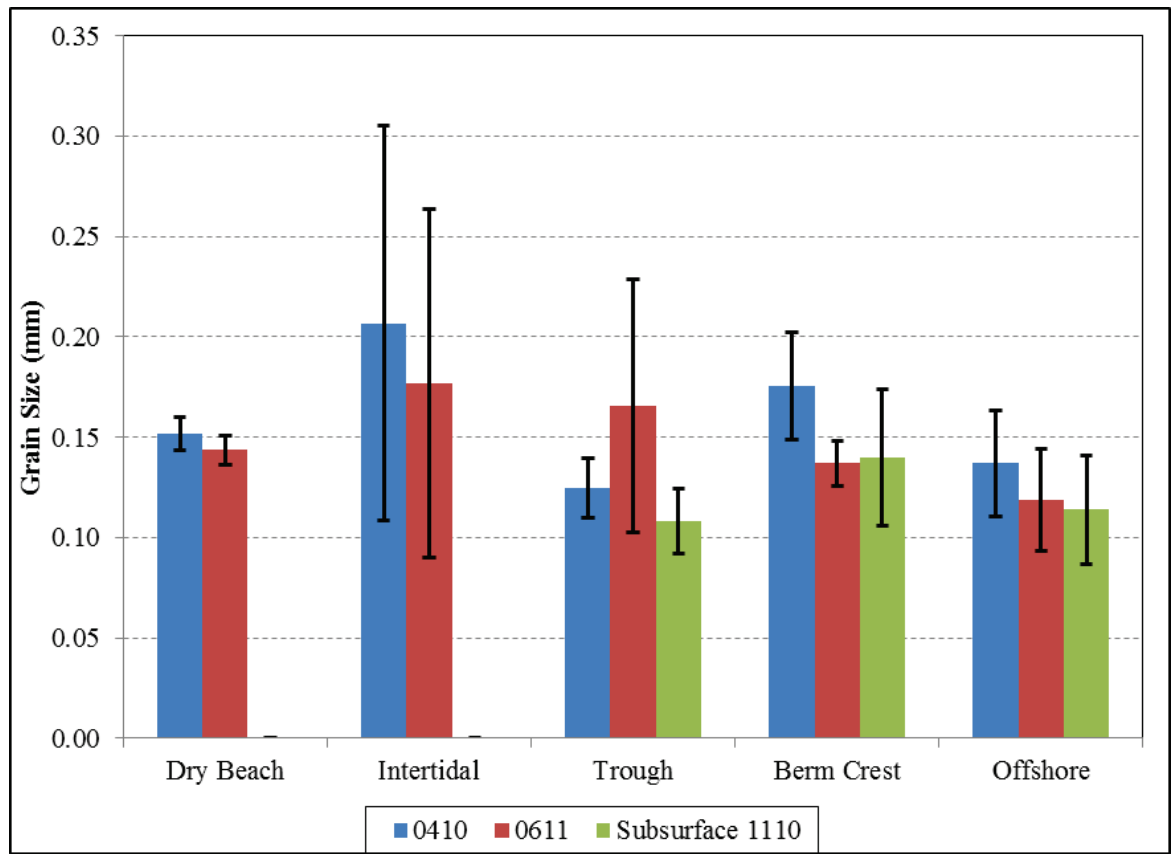

Figure 7 . Spatially averaged grain sizes in the berm project area showing coarsening in the trough and fining offshore, indicating that fine material in the trough moved to the offshore. The beach remained stable throughout the study period, showing that fine material associated with the placement did not impact the dry beach. Modified from Brutsché et al. (2014).

\section{LESSONS LEARNED FROM FORT MYERS BEACH}

Sustainability of strategic placement site. Figure 8 shows the variance of the nearshore berm profile lines during each survey period from the average profile line of the greater study area. Detailed information on calculations can be found in Brutsché et al. (2014). Overall, the average variance from the average profile decreased throughout the entire study period, and by May 2013, the average variance was approximately equal to the pre-placement average variance, indicating that the berm had equilibrated by that point. In other words, the profiles had returned to a shape similar to that of the average (or equilibrium) profile for the study area. As mentioned in the results section, the May 2013 profile shape was similar to the pre-placement shape, albeit shifted slightly offshore. Therefore, the strategic placement site may be considered sustainable as it can potentially be used for future EWN projects in this location. However, consideration must be given to the offshore shift of the profile as it may impact the cross-shore location of future placements. 


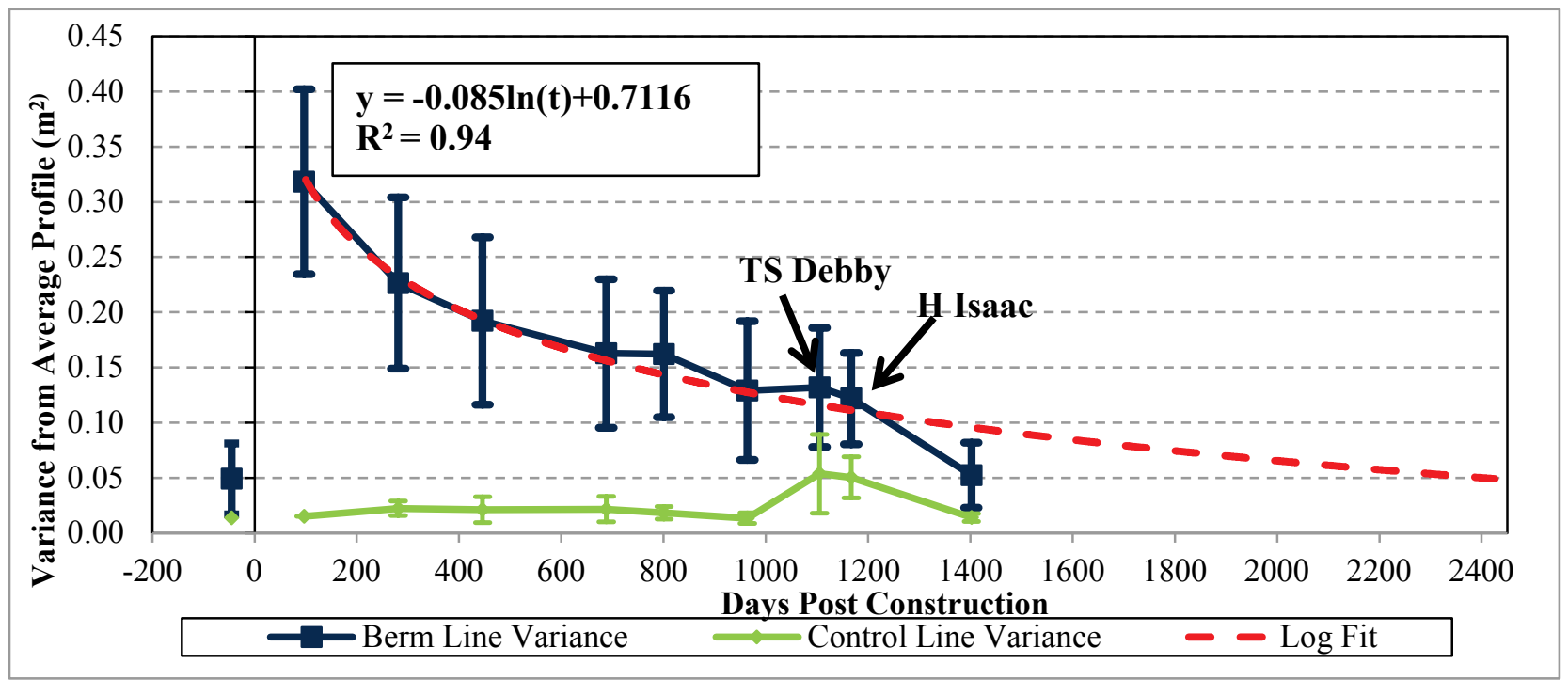

Figure 8. Average variance from the average profile of the study area. From Brutsché et al. (2014).

Beneficial use: Addition of sediment to the dry beach. One of the major goals of strategic placement of dredged materials is to place material in such a way as to maximize the benefits while also minimizing negative impacts of the projects to the surrounding area. In the case of nearshore berm placement, one way this can occur is the nourishment of the dry beach by the nearshore berm. In the case of Fort Myers Beach, this can be seen in the overall widening of the dry beach (Figure 9). With the exception of one profile, all of the profiles within the berm project area gained dry beach width and volume, adding up to approximately $27 \mathrm{~m}$ of beach as compared to the pre-placement profile. A total of $17,500 \mathrm{~m}^{3}$ (approximately $10 \%$ of the initial volume of the nearshore berm) of sediment was gained on the dry beach in the berm project area.

Note that in the southeast control area, many profiles also gained sediment on the dry beach. Profiles immediately adjacent to the berm gained the most sediment, up to $15 \mathrm{~m}$ in dry beach width. On average, profiles in the distant southeast control (i.e., FMB 1-8) area gained a total of $0.14 \mathrm{~m}^{3} / \mathrm{m}$ of sediment volume and $1.3 \mathrm{~m}$ of dry beach width while profiles adjacent to the berm (i.e., FMB 9-16) gained a total of $1.3 \mathrm{~m}^{3} / \mathrm{m}$ of sediment and $9 \mathrm{~m}$ of dry beach width. This indicates that although nearshore berms are built in a similar shape as a submerged breakwater with similar purposes, unlike submerged breakwaters, nearshore berms are not permanent and will eventually align with nature even if they are dramatically out of equilibrium. 


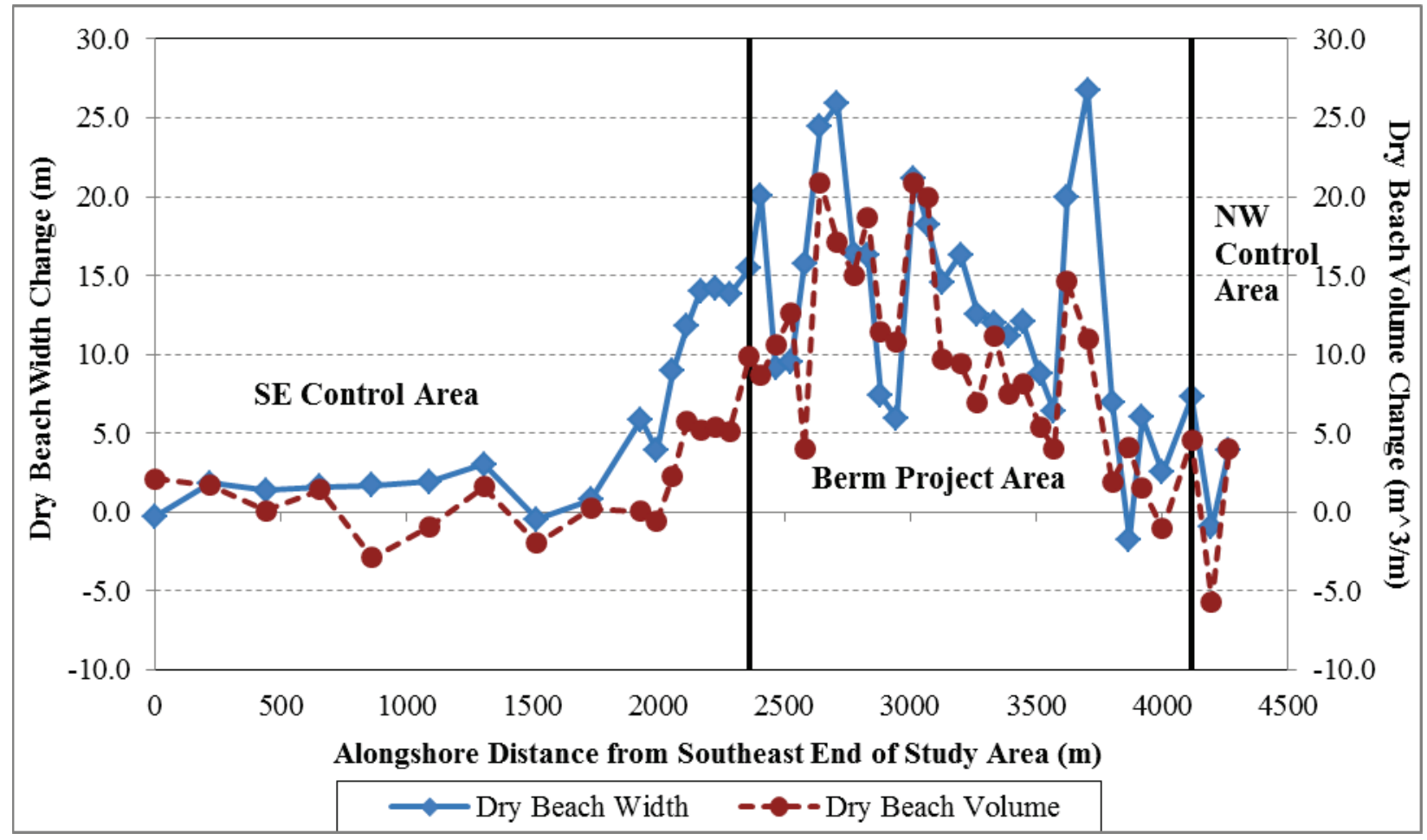

Figure 9. Dry beach width and volume change between April 2010 and May 2013. From Brutsché et al. (2014).

Use of mixed sediments in strategic placement projects. The use of various types of mixed sediments in strategic placement projects is an important practice of EWN that balances regional sediment management principles with EWN concepts. The goal is to place material in such a way that fine sediment may be winnowed from the placement sediment and ideally disperse to quiescent areas where fine sediment typically settles. In the case of Fort Myers Beach, this technique proved to be successful. The construction of the berm allowed fine sediment to deposit within the relatively low energy trough area landward of the berm, which was then transported offshore through surf zone processes. This maximized the benefit of using initially unacceptable beach material with natural processes that promoted the onshore movement of coarser beach quality material and the transportation of the less desirable material offshore. The winnowing of fine sediment also implies that this site and sites like it may be used in future strategic placement projects involving the intentional placement of mixed material in the nearshore in such a way that fine material transports away from the initial placement, and the remaining coarser, beach-quality sediment may be dredged and used in another nourishment project.

SUMMARY: Fort Myers Beach provides a good example of the successful implementation of EWN concepts. The nearshore berm moved onshore, nourished the beach, and the profiles reached their pre-placement equilibrium shape. Subsequently, much of the placed material is no longer within the designed area, which can now be used for future projects. However, future placements may need to be shifted seaward as the profiles within the berm project area gained sediment. The adjacent beaches benefited from the additional sediment in the littoral zone, as seen through increases in width and volume of the dry beach. Overall, the profiles in the berm project area shifted seaward, indicating volume gain throughout the profiles. The profiles 
immediately adjacent to the berm project area experienced a gain of up to $15 \mathrm{~m}$ in dry beach width, emphasizing the benefits of the berm while minimizing negative impacts. Additionally, profiles did not show erosion of the dry beach in the lee of the berm following the passages of two tropical systems, indicating the shore protection provided by the berm.

ADDITIONAL INFORMATION: For additional information regarding this EWN TN, please contact Dr. Katherine Brutsché (601-634-6174; Katherine.E.Brutsche@usace.army.mil). For information about EWN, please contact Dr. Todd Bridges at 601-634-3626 or Todd.S.Bridges@usace.army.mil. This technical note should be cited as follows:

Brutsché, K. E., and C. E. Pollock. 2017. Strategic placement of mixed sediment in the form of a nearshore berm along Fort Myers Beach, Florida. EWN Technical Notes Collection. ERDC TN-EWN-17-1. Vicksburg, MS: U.S. Army Engineer Research and Development Center. http://dx.doi.org/10.21079/11681/21616

ACKNOWLEDGEMENTS: This study was funded by the USACE Coastal Inlets Research Program (CIRP) and Regional Sediment Management (RSM) Program, executed by the Engineer Research and Development Center (ERDC), Coastal and Hydraulics Laboratory (CHL). Additional funding was also provided by Engineering With Nature (EWN), executed by ERDC, Environmental Laboratory (EL). Appreciation is expressed to Jim Lagrone of the Jacksonville District (SAJ) for information on the construction and design of the nearshore berm and for providing the District perspective on the goals for this project. Additionally, appreciation is expressed to the numerous graduate students from the University of South Florida for assisting with field data collection.

\section{REFERENCES}

Balsillie, J. H., and R. R. Clark. 1992. The Gulf Coast of Florida: Overview of physiography, geology, and historical shoreline change. Report for the Florida Department of Natural Resources, Division of Beaches and Shores. Tallahassee, FL.

Beck, T. M., and P. Wang. 2009. Influences of channel dredging on flow and sedimentation patterns at microtidal inlets, west-central Florida, USA. In Proceedings of Coastal Dynamics 2009: Impacts of Human Activities on Dynamic Coastal Processes; Tokyo, Japan, 7-11 September 2009. Singapore: World Scientific.

Brutsché, K. E. 2011. First year sedimentological characteristics and morphological evolution of an artificial berm at Fort Myers Beach, Florida. Master's thesis. Tampa, Florida: University of South Florida.

Brutsché, K. E., and P. Wang. 2012. First year morphological evolution of an artificial berm at Fort Myers Beach, Florida. ERDC/CHL CHETN-II-54. Vicksburg, MS: U.S. Army Engineer Research and Development Center.

Brutsché, K. E., P. Wang, T. M. Beck, J. D. Rosati, and K. R. Legault. 2014. Morphological evolution of a submerged artificial nearshore berm along a low-wave microtidal coast, Fort Myers Beach, west-central Florida, USA. Coastal Engineering 91: 29-44. doi: 10.1016/j.coastaleng.2014.04.010.

Florida Department of Environmental Protection. 2009. Matanzas Pass channel restoration and maintenance dredging. File No. 158893-005-JC and 158893-006-BV. Tallahassee, FL.

Florida Department of State. 2001. Rules and procedures for application for coastal construction permits: Design, siting, and other requirements. Florida Administrative Code 62B-41.007 j and k. Tallahassee, FL.

Larson, M., and N. C. Kraus. 1994. Temporal and spatial scales of beach profile change, Duck, North Carolina. Marine Geology 117: 75-94. 
Poff, M. T., and M. F. Stephen. 1998. Southwest Florida regional sediment budget. In Proceedings, National Conference on Beach Preservation Technology, St. Petersburg, Florida.

Roberts, T. M., and P. Wang. 2012. Four-year performance and associated controlling factors of several beach nourishment projects along three adjacent barrier islands, west-central Florida, USA. Coastal Engineering 7: 21-39.

U.S. Army Corps of Engineers (USACE). 1969. Beach erosion control study on Lee County, Florida. Jacksonville, FL: USACE, Jacksonville District.

. 2001. Lee County, Florida shore protection project (Gasparilla and Estero Islands) general reevaluation report with final environmental statement. Jacksonville, FL: USACE, Jacksonville District.

Walton, T. L. 1973. Littoral drift computations along the coast of Florida by means of ship wave observation. Coastal and Oceanographic Engineering Laboratory Technical Report 15. Gainesville, FL: University of Florida.

Wang, P., K. E. Brutsché, J. W. Lagrone, T. M. Beck, J. D. Rosati, and L. S. Lillycrop. 2013. Performance monitoring of a nearshore berm at Fort Myers Beach, Florida: Final report. ERDC/CHL TR-13-11. Vicksburg, MS: U.S. Army Engineer Research and Development Center. 